\title{
BIRO JODOH ONLINE: KEGUNAAN DAN DAMPAK
}

\author{
Regita Amelia ${ }^{1}$, Rizqa febry Ayu² \\ ${ }_{1}^{1}$ Universitas Islam Negeri SunanKalijaga, Yogyakarta \\ e-mail: regitaame161@gmail.com \\ ${ }^{2}$ Universitas Islam Negeri Sunan Kalijaga, Yogyakarta \\ email: rizqa9732@gmail.com
}

\begin{tabular}{|l|l|l|}
\hline Submit: 28-08-2020 & Direvisi:15,25-10-2020 & Dipublish: 18-12-2020 \\
\hline
\end{tabular}

\begin{abstract}
Along with the development of technology in the digital era, it is increasingly easier to access communication. Various applications used in the process of finding a partner. One of them is the emergence of an online matchmaking application which is experiencing rapid development. So that the transition to the concept of matchmaking from conventional to online is not new, along with the times. This research focuses on the implications for today's online matchmaking agencies. This research used a qualitative approachand using descriptive analytical method. The results showed thatonline matchmaking agencies, although they have positive and negative impacts for their users, but it is not an obstacle for partner seekers through cyberspace.
\end{abstract}

Kata kunci: Biro Jodoh Online, Kegunaan, Dampak

\section{PENDAHULUAN}

$\mathbb{R}$ asa ketertarikan terhadap lawan jenis merupakan hal yang wajar terjadi pada manusia ketika telah memasuki masa pubertas yang umumnya dimulai pada usia 13 tahun. Ketertarikan terhadap lawan jenis disebabkan karena pada masa pubertas terjadi perubahan hormonal yang mengakibatkan munculnya dorongan-dorongan seksual yang ditunjukkan dengan aktivitas yang sudah mulai tertarik dengan lawan jenis. Agama Islam mengatur umatnya untuk menyalurkan rasa ketertarikan terhadap lawan jenis dalam hubungan pernikahan yang merupakan satu-satunya jalan yang halal bagi perempuan dan laki-laki yang saling senang satu sama lain agar dapat bersama.

Pada masa tradisional menikah adalah hal yang cukup mudah karena pada saat memilih calon istri atau calon suami akan dibantu oleh para sahabat yang berperan sebagai perantara atau istilah lain yang akrab di kalangan para pemuda dengan "mak comblang". Semakin dengan adanya perkembangan zaman, "mak comblang" sudah sangat berkembang semakin maju para "mak comblang" membuka lembaga khusus yang biasa disebut dengan biro jodoh, jadi semakin terkonsep dalam melaksanakan perjodohan.

Pernikahan menurut Islam adalah akad yang menimbulkan kebolehan bergaul antara laki-laki dan perempuan dalam tuntutan naluri kemanusian dalam kehidupan, dan menjadikan kedua pihak secara timbal balik memiliki hak-hak dan kewajiban-kewajiban. Proses dalam menentukan pasangan untuk menjalani kehidupan pernikahan beragam. Ada 
yang memilih berpacaran untuk mencari kecocokan satu sama lain untuk membina rumah tangga, ada yang dijodohkan atas persetujuan yang bersangkutan, ada yang dijodohkan tanpa persetujuan yang bersangkutan (kawin paksa), dan ada pula yang memilih pernikahan yang didahului dengan perkenalan melalui aplikasi biro jodoh online baik yang menggunakan konvensional dan Syariah.

Perkenalan dalam Islam disebut juga dengan taaruf, yang berasal dari kata ta'arafa-yata'arafu yang artinya saling mengenal. Hal ini juga terdapat dalam surat Al-Hujurat ayat 13, yang artinya: "Hai manusia sesungguhnya kami telah menciptakan kalian dari seorang pria dan seorang wanita, lalu menjadikan kalian berbangsa-bangsa dan bersuku-suku agar kalian saling mengenal."

Hal itu didukung seiring dengan perkembangan yang semakin pesat di era digital. Kehadiran berbagai macam aplikasi biro jodoh online kini memudahkan masyarakat dalam mencari pasangan berdasarkan kriteria yang diinginkan. (Tarigan, 2017: 20) Namun, yang perlu diperhatikan berbagai aplikasi tersebut mempunyai kekurangan dan kelebihan masing-masing. Hadirnya aplikasi biro jodoh online ditengah pandemi covid 19 saat ini memberikan dampak dan bermanfaat bagi penggunanya dengan situasi social distancing saat ini.

Dengan hadirnya berbagai macam aplikasi biro jodoh online yang kini memudahkan masyarakat untuk mencari pasangan berdasarkan kriteria yang diinginkan, namun dari beberapa aplikasi berbeda yang menyediakannya, masingmasing memiliki kelebihan dan kekurangan yang berbeda. Adanya aplikasi biro jodoh online ini memberikan dampak serta bermanfaat bagi masyarakat dengan kesibukan dan keseharian dengan segudang aktivitas padat sehingga tidak memiliki cukup waktu untuk menacari pasangan tetapi memiliki niat untuk menjalin hubungan serius untuk menuju ke jenjang perkawinan.

Oleh karena itu, penelitian ini berusaha untuk menganalisa tentang biro jodoh online. Kemudian penelitian ini menjadi suatu upaya yang digunakan pengguna biro jodoh online untuk mencari pasangan melalui jejaring sosial. Dalam artikel ini, penulis memfokuskan pada dua poin penting yaitu:

1. Bagaimana konsep biro jodoh online?

2. Bagaimana manfaat dan dampak penggunaan biro jodoh online?

\section{METODE PENELITIAN}

1. Jenis Penelitian

Kajian penelitian ini merujuk pada kajian pustaka. Dengan sebab itu, penelitian ini berupa library research atau penelitian kepustakaan, yaitu data-data yang didapat bersumber dari literature yang memiliki keterkaitan dengan tema yang diteliti seperti buku, artikel, dokumen, jurnal dan karya-karya ilmiah lainnya. (Zed, 2008: 20)

\section{Teknik Pengumpulan Data}

Di dalam mengumpulkan data dalam penenlitian ini menggunakan teknik kualitatif deskriptif, yaitu penelitian berdasarkan penjelasanpenjelasan dari permasalahan terhadap objek yang dikaji dengan analisa dan lain-lain. Dalam hal ini, peneliti menggambarkan bagaimana kegunaan dan dampak dari biro jodoh online terhadap para penggunanya. Penelitian tipe deskriptif kualitatif ialah sebuah cara dalam sebuah penelitian dengan menjelaskan objek yang dikaji baik berupa peristiwa, 
tempat maupun perilaku tertentu secara detail. Pengumpulan data menggunakan metode ini digunakan supaya penelitian yang dilakukan lebih jelas dan mudah dipahami terkait objek penelitian dengan di dalamnya mencoba menjelaskan, mendeskripsikan, menafsirkan dan menuturkan peristiwa yang diteliti. Adapun dengan metode ini dapat diketahui bagaimana situasi, hubungan, pandangan, perilaku, pengaruh dan kelainan serta kecenderungan dari sebuah peristiwa atau objek yang dikaji.

\section{KONSEP BIRO JODOH ONLINE}

Allah SWT telah banyak menyebutkan di dalam kitab-Nya tentang syariat pernikahan dan menjadi landasan dalam mengarungi hidup berpasangan sebagi makhluk sosial disebabkan mengandung nilai-nilai keluhuran dan tujuan hidup sebagai ciptaan Tuhan yang tinggal di dunia. Sebagai upaya memperoleh hidup yang bahagia dan jauh dari kesesatan, Allah SWT memberikan pedoman bagi manusia berupa hukum dan syariat islam untuk ditaati manusia yang menginginkan kehidupan yang bahagia. (Azzam, 2014: 39)

Perkawinan termasuk salah satu bentuk peribadatan dan ketaatan. Seseorang yang telah menikah dianggap telah menyempurnakan syarat peribadatannya sebagai hamba Tuhan, karena dengan menikah setiap perbuatan baiknya dinilai lebih dan bisa menjaga hawa nafsunya dari perbuatan yang mengarah pada perbuatan zina. (Ash-Shobuni, 2008: 20)
Tujuan utama dari pernikahan ialah untuk mencapai kehidupan yang penuh dengan kasih, cinta, ketenangan, kesejahteraan dan ketentraman hidup. Tujuan seseorang menikah sesungguhnya bukan sekedar untuk memenuhi hasrat biologisnya kepada pasangannya, namun terdapat maksud yang utama di balik hal demikian yang kaitannya dengan agama, psikologi dan sosial. (Azzam, 2014: 39)

Allah telah menjadikan manusia saling berpasangan dan terdiri dari beberapa suku dengan tujuan saling mengenal dan membantu satu sama lain. Seperti yang ditegaskan dalam al-Qur'an surat al-Hujurat ayat 13 yang berbunyi:

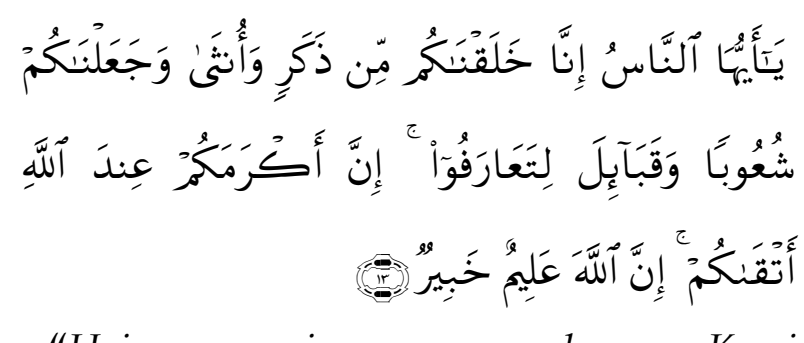

"Hai manusia, sesungguhnya Kami menciptakan kamu dari seorang laki-laki dan seorang perempuan dan menjadikan kamu berbangsa-bangsa dan bersuku-suku supaya kamu saling kenal-mengenal. Sesungguhnya orang yang paling mulia diantara kamu disisi Allah ialah orang yang paling takwa diantara kamu. Sesungguhnya Allah Maha Mengetahui lagi Maha Mengenal."(QS. al-Hujurat [49]: 13)

Ayat di atas menjelaskan bahwa alQur'an memiliki point penting terkait dengan hubungan di dalam berhubungan dengan orang lain baik perempuan maupun laki-laki. Konsep yang dibangun pada ayat tersebut mensyariatkan untuk saling mengenal bagaimana karakter, keluarga, budaya sosial ataupun agama 
antar sesame agar terjalin kehidupan yang harmonis. Apabila antara laki-laki dan perempuan menemukan kesesuaian dan saling menyukai maka,kedua belah pihak bisa mengajukan untuk menjalin hubungan menuju pernikahan berdasarkan persetujuan dari kedua orang tua mereka.(Tihami dan Sohari Sahrani, 2014: 23)

Sebelum suatu pasangan memutuskan untuk melakukan perkawinan, maka dibelakangnya memiliki proses yang berbeda-beda dalam berhubungan. Salah satunya seperti konsep berpacaran yang dilakukan pada kalangan remaja, ada yang memilih dilakukan sendiri tanpa paksaan dan melalui proses taaruf, ada yang melalui perjodohan atau adanya pihak ketiga yang membantu melancarkan proses pencarian pasangan, ada yang memilih dijodohkan oleh orang tua ataupun keluarga dekat. Hal tersebut dilakukan agar bisa saling memahami kemudian menjalin hubungan di antara laki-laki dan perempuan melalui cara yang berbeda-beda dan juga sesuai dengan keinginan masing-masing pihak.

Biro jodoh merupakan sebuah lembaga yang menyediakan jasa dalam mencari pasangan atau jodoh baik perempuan maupun laki-laki agar bisa menikah secara halal. Namun sebagian biro jodoh juga tidak mempermasalahkan apabila laki-laki dan perempuan menjalin hubungan dalam bentuk pacaran sebelum mereka menempuh ke jalur pernikahan. Meski demikian tidak jarang terjadi ketidakselarasan kedua belah pihak antar laki-laki dan perempuan sehingga tidak bisa berlanjut untuk menikah. Sementara perjodohan seperti yang disebutkan dalam KBBI memiliki arti perkawinan, menjodohkan atau perihal jodoh. (Sita, 2013: 4)

Menurut fiqh bahwa perkawinan merupakan dasar utama dalam menjalan- kan hubungan di maysarakat dan cara yang sah dalam meneruskan dan mengembangkan anak keturunan, sebagaimana firman Allah SWT dalam QS. An-Nahl ayat 72 yang berbunyi:

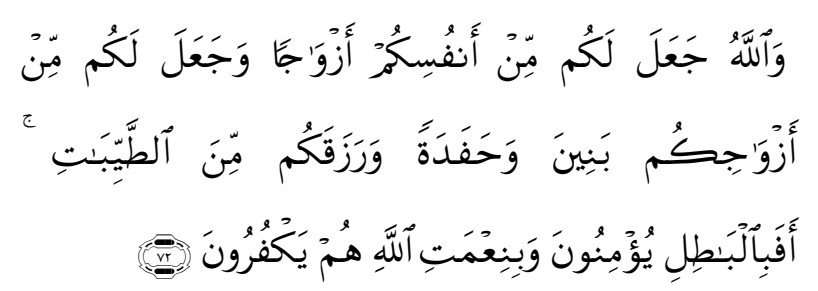

"Allah menjadikan bagi kamu isteri-isteri dari jenis kamu sendiri dan menjadikan bagimu dari isteri-isteri kamu itu, anakanak dan cucu-cucu, dan memberimu rezeki dari yang baik-baik. Maka mengapakah mereka beriman kepada yang bathil dan mengingkari nikmat Allah?" (QS. an-Nahl [16]: 72)

Ayat tersebut memberikan gambaran bahwa pernikahan ialah persetujuan antara perempuan dan lakilaki dengan tujuan melepaskan hasrat biologisnya dengan cara yang halal dan melalui pernikahan menjadikan hidup seseorang bahagia dan harmonis karena telah memiliki pasangan yang sah serta berkeluarga. (Rasyid, 2010: 374)

Mengenai perjodohan dalam Islam dijelaskan dalam hadist yang diriwayatkan dari Abdullah bin Mas'ud r.a dari Rasulullah SAW yang artinya:

"Abdullah Ibnu Mas'ud r.a berkata: Rasulullah Saw bersabda pada kami:"Wahai generasi muda, barang siapa diantara kamu telah mampu berkeluarga (memberi mahar dan jima") hendaknya ia kawin, karena ia dapat menundukkan pandangan dan memelihara kemaluan. Barang siapa belum mampu hendaknya berpuasa, sebab ia dapat mengendalikanmu."(HR. Muttafaq Alaihi). (Al-Asqalani, 2000: 374)

Hukum menikah adalah disunnahkan apabila telah mampu menafkahi perempuan dan mampu untuk membayar maskawin serta memiliki 
keinginan untuk menikah. Namun apabila tidak memiliki biaya dan belum siap jiwa untuk menikah maka disunnahkan untuk berpuasa. (Uwaidah, 1998: 376-377)

Di dalam Undang-Undang tidak dijelaskan mengenai biro jodoh, hanya saja dalam pasal 1 UU perkawinan Nomor 1 Tahun 1974 merumuskan pengertian yaitu: perkawinan ialah hubungan antara laki-laki dan perempuan menjadi sebuah keluarga (suami-istri) agar menjadi keluarga yang harmonis dan menjalankan syariat agama. (Syarifuddin, 2003: 75-76)

\section{PERGESERAN PEMANFAATAN BIRO JODOH OFFLINE KE ONLINE}

Pada era modern sekarang ini sebagai akibat dari kemajuan ilmu pengetahuan dan teknologi sehingga membuat segala aktivitas menjadi serba mudah dan informasi dapat dijangkau dengan cepat (Hakim, 2018: 275). Semenjak adanya internet, penggunaan media sosial mengalami perkembangan yang sangat pesat terutama di kalangan para pemuda-pemudi. Hal ini menjadikan adanya aplikasi atau sosial media yang menyediakan jasa mencari jodoh secara online. Tetapi tidak semuanya berakhir dengan keberhasilan. (Waluyo, 2019: 21) Di dalam memilih pasangan hidup pada era yang sekarang ini telah dipermudah melalui media sosial.

Pada zaman orang-orang terdahulu pernikahan ditentukan dan disepakati oleh kedua orang tua perempuan dan laki-laki. Demikian ini terjadi sebab para orang tua menganggap pernikahan bukan hanya penyatuan dua buah hati yang saling mencintai namun merupakan penyatuan antara keluarga perempuan dan laki-laki sehingga orang tua memiliki hak dalam menentukan pasangan anakanak mereka.

Pada era yang orang cenderung serba instant sekarang ini hingga pencarian jodoh pun dibuatkan aplikasi sosial media. Melalui aplikasi tersebut seseorang bisa mencari pasangan sesuai dengan yang diinginkan. Hubungan bisa berlanjut menuju jenjang pernikahan jika kedua belah pihak sepakat untuk menikah. Orang-orang yang memang penggunan sosial media secara aktif akan menilai bahwa sosial media adalah kegiatan yang menyenangkan dan menjanjikan sehingga menjalin sebuah hubungan pun bisa melalui ponsel dan jarak jauh serta bisa dilakukan kapan dan dimana pun. (Bungin, 2008) Melalui media perantara online setiap orang yang mencari pasangan dapat memilih sesuai dengan kriteria yang diinginkan dengan mendaftarkan diri di sebuah web atau aplikasi yang diinginkan. (Azzulfa, 2020: 39)

Seiring dengan perkembangan teknologi, kini pemanfaatan internet sudah digunakan oleh semua kalangan masyarakat. Internet merupakan jejaring sosial yang berperan penting dalam menjaga hubungan antar sesama manusia. Beberapa kegiatan kini sudah serba online, mulai dari berbelanja, transportasi hingga dalam memilih jodoh. Menurut hasil penelitian (We are social) tahun 2020 terdapat 175,4 juta pengguna dan mengalami peningkatan sebanyak 17 persen atau 25 juta pengguna dari tahun sebelumnya. Tidak heran apabila ditahun 2020 mengalami peningkatan pengguna 
untuk tetap bersosialisasi dimasa pandemik covid 19 seperti ini.Di Indonesia, situs biro jodoh online pertama kali muncul pada awal tahun 1990-an, saat adanya fenomena media sosial microblogging ketika Friendster mulai banyak digunakan.(Antar Venus dan Hikamul Had Ridwan, 2015: 1)

Kebutuhan masyarakat akan adanya aplikasi pencarian jodoh seiring dengan tingkat kesibukkan orang-orang kota dalam bekerja setiap hari. Faktor waktu yang terbatas menjadikan mereka memilih menggunakan sosial media dalam menjalin hubungan dengan orang lain. Hal ini tidak bisa dipungkiri karena harus bekerja dari pagi hingga malam dan cara yang tepat untuk memenuhi kebutuhan hidup dari makan hingga mencari pasangan digunakan kemajuan teknologi komunikasi seperti ponsel. Serta aplikasi tersebut juga dapat dimanfaatkan bagi anak-anak muda yang memiliki sifat introfert (tertutup) untuk mendapatkan pasangan dengan mudah. Biasanya, yang paling banyak menggunakan aplikasi tersebut rata-rata yang berumur 20-30 tahun. Di Indonesia sendiri telah ada berbagai aplikasi pencarian jodoh seperti tinder, setipe dan bee'talk yang bisa diunduh melalui smartphone dan digunakan sesuai keinginan pengguna. (Herdianti, 2018)

Dewasa ini perkembangan teknologi berbasis digital sudah semakin pesat, untuk memudahkan manusia dalam melakukan aktifitas serta mencari kebutuhannya. Seperti halnya dalam mencari jodoh yang sekarang dapat dicari dengan digital. Berbeda dengan dahulu sebelum adanya internet, pencarian atau pemilihan jodoh diatur dan dikontrol oleh orang tua. Kalaupun ada biro jodoh yang tersedia hendaknya bersifat konvensional dalam artian tidak harus melalui media sosial yaitu dengan cara bertemu secara langsung. (We Are Social, n.d.) Biro jodoh konvensional mempunyai kekurangan seperti harus berkunjungan ke tempat penyedia biro jodoh offline untuk mendaftar. Sehingga membutuhkan waktu dan proses yang dinilai kurang efektif dan efisien di segala bidang. Namun kelebihan dari biro jodoh offline yaitu setiap pengguna tidak dapat membohongi data dan sesuai aslinya serta tidak ada kejahatan online(cyber crime).

Perbedaan tata cara atau proses dari biro jodoh online yang konvensional dan syariah juga sangat berbeda. Jika biro jodoh online yang konvensional tidak diawasi oleh pemilik aplikasi atau web, lebih bebas dan leluasa dalam memilih dan berkomunikasi dengan satu sama lain. Biro jodoh online yang syariah lebih menerapkan dari aturan syariat Islam dengan cara taaruf. Proses taaruf sampai ke pernikahan hanya 3 bulan dan adanya batasan-batasan dalam mengajukan pertanyaan. Serta diawasi oleh pemilik akun biro jodoh online tersebut.

Salah satu contoh aplikasi biro jodoh online yang menggunakan cara taaruf yaitu Mawaddah Indonesia, langkah-langkah proses taaruf diawali dengan pengisian biodata secara lengkap dan detail, lalu mengajukan taaruf atau diajukan taaruf, jika sudah masuk dalam proses taaruf, dilanjutkan dengan mengajukan 11 pertanyaan. 6 Pertanyaan untuk calon suami tersebut meliputi: bagaimana pemahaman tentang keluarga serta visi misi pernikahan, bagaimana ibadah yang dijalaninya, bagaimana pemahaman tentang peran, hak dan kewajiban suami dan istri, bagaimana mengatur emosi dan konflik, bagaimana caranya mengatur diri dan keuangan serta cukup tanya apa yang membuatnya tertarik. 5 pertanyaan untuk calon istri meliputi: bagaimana shalat lima waktu- 
nya, bagaimana kedekatannya dengan ayah, sudah siapkah untuk mendidik anak, apa yang akan dia lakukan jika terjadi hal buruk dalam pernikahan, serta bagaimana selama ini dia mengelola uang. Adapun Batasan-batasan dalam proses taaruf adalah tidak boleh bertanya aib/masa lalu dan kontak pribadi.

Hal ini sesuai dengan aturan hukum Islam mengenai pengertian taaruf, yang mana taaruf merupakan proses saling mengenal antara dua orang lawan jenis yang ingin menikah. Jika diantara mereka berdua ada kecocokan maka bias berlanjut ke jenjang pernikahan, namun jika tidak maka proses berhenti dan tidak dilanjutkan. Sedangkan tata cara taaruf yang sesuai dengan syariat Islam adalah: tidak berkhalwat dan hendaknya memandang tanpa syahwat.

Aplikasi tinder adalah aplikasi menacri pasangan terbanyak digunakan di Indonesia yang mulai dibuat pada tahun 2012. Pada ajang Tech Crunchyang berlangsung sampai tahun 2015, aplikasi tinder memeperoleh penghargaan dengan taksiran penggunaan sebanyak 50 juta orang dan pengguna aktif sebanyak 10 juta hal ini hampir menyamai penelitian yang dilakukan PEW yakni pengguna erbanyak aplikasi tinder berkisaran 25 sampai 34 tahun yang menyentuh angka total $45 \%$ pengguna. Mengaplikasikan tinder sangat mudah yang menyebabkannya banyak digunakan oleh orang, bentuk penggunaan aplikasi tinder tidak perlu melakukan registrasi yang sulit pengguna cukuplog indenganfacebook atau nomer ponsel, apabila telah mempunyai akun facebook maka pengguna memasukan emailnya disertai sandinya dan bisa juga membuat akun facebook yang baru dengan mengklik sign up.

Penggunan aplikasi tinder kemudian diarahkan agar bisa digunakan menggunakan akun facebook. Setelah itu pengguna memiliki akun tinder dan sudah dapat digunakan sesuai keinginan. Aplikasi ini didesain berbasis mobile phoneuntuk memberikan kemudahan pengguna sosial media dalam berkenalan dan mencari pasangan. Penggunaan aplikasi tinder yang mudah sangat sederhana menjadikan para penggunanya tidak terbatas usia. Hal yang membuat pengguna merasa tertarik ketika menekan tombol "like" antar sesama pengguna memperlihatkan adanya ketertarikan. Hubungan ini akan berlanjut apabila keduanya terus saling menghubungi. Rasa ketertarikan pertama kali akan terjadi ketika melihat foto profil masing-masing. Hubungan tidak bisa berlanjut jika salah satu tidak menyukai kenalannya. Kegunaan sosial media sangat banyak sehingga urusan mencari jodoh pun telah disediakan berupa aplikasi khusus.

Pemanfaatan internet dalam mencari pasangan sudah dilakukan sejak lama, mulai dari hanya sekedar mencari pasangan kencan, seperti Okcupid (sejak 2004) dan Tinder (sejak 2012) yang merupakan media sosial yang dibuat khusus untuk mencari pasangan kencan, maupun situ-situs mencari pasangan lebih Islami, yaitu mencari pasangan taaruf, di antaranya rumahtaaruf.com, ayotaaruf.com dan mawaddahindonesia. com, dan melalui situs-situs seperti inilah istilah taaruf online mulai terbentuk. Kemudian taaruf online tidak hanya terjadi dalam situs-situs yang memang 
dibuat khusus untuk itu, tapi juga terjadi di media sosial yang umum digunakan, seperti facebook dan Instagram. Banyak orang yang kemudian membentuk grup atau akun khusus taaruf di media sosial Facebook, maupun membuat akun-akun taaruf pada Intagram. Taaruf online via Instagram merupakan proses taaruf yang difasilitasi secara online oleh akun-akun taaruf pada media sosial Instagram. Jika pada taaruf offline para pelaku taaruf berkenalan melalui perantara oleh orang yang mengenal pelaku taaruf secara personal, maka pada taaruf online perkenalan dilakukan di media sosial Instagram, yakni diperantarai oleh akunakun yang memang dibuat untuk tujuan taaruf dimana pemilik dan admin akun tersebut tidak mengenal para peserta secara personal (akun anonim). (Lestari, 2019: 14)

Penggunaan tinder dalam mencari jodoh memiliki pengaturan sendiri. Bagi yang telah bekerja dan memiliki usia 25 tahun ke atasa cenderung akan lebih mudah mendapat pasangan dari pada yang belum memiliki pekerjaan karena hal ini telah diatur sendiri dalam pengaplikasian tinder. Usia yang dianggap telah matang dan memiliki pekerjaan menjadi tolak pikir pembuatan pengaturan tersebut karena pada kondisi demikian akan sulit bagi pengguna hanya untuk bermain-main dalam menjalin hubungan. Berbeda dengan yang usia di bawah 25 tahun apalagi yang belum memiliki pekerjaan yang dengan mudah gonta-ganti pasangan karena belum ada persiapan menuju jenjang pernikahan seperti persiapan biaya, nafkah dan mental. Pengguna yang masih belum bekerja terkadang memakai aplikasi tinder berdasarkan tujuan yang berbeda, ada yang bermaksud bermain-main, mencari teman kencan semalam, pacaran tanpa keseriusan bahkan ada yang sampai menjajakan dirinya. Sementara yang berusia 25 tahun ke atas dan memiliki pekerjaan cenderung serius dalam menjalin hubungan karena sibuk bekerja dan mempersiapkan biaya serta mental untuk menikahi pasangannya dan keinginan untuk menjalin keluarga yang bahagia.

Hukum biro jodoh adalah "mubah". Demikian ini berdasarkan teknis pelaksanaannya karena tidak melanggar nilainilai agama dan moral serta untuk memudahkan seseorang dalam mencari pasangan pada zaman yang serba gadget sekarang. Secara hukum Islam perkawinan merupakan akad dari calon mempelai secara sah. Akad yang diucapkan telah mengindikasikan bahwa perempuan telah sah menjadi istri dan harus mentaati suaminya karena orang tua perempuan telah menyerahkan anaknya pada laki-laki kemudian diterima oleh laki-laki tersebut (qabul) yang disaksikan oleh dua orang saksi maupun lebih. (Hadikusuma, 1990: 11)

Aplikasi biro jodoh online bisa dikatakan aplikasi yang tren dan modern yang banyak digunakan masyarakat untuk menemukan pasangan, berbeda dengan model ta'aruf yang digunakan masyarakat pada zaman-zaman tradisional. Kedua model ini memiliki perbedaan, aplikasi biro jodoh online dengan rumah-rumah ta'aruf yang sering kali mengadakan kajian ta'arufbisa dikatakan sama karena sama-sama menyediakan dan mempermudah seseorang dalam mencari pasangan.

Berikut merupakan pendapat dari para pakar, antara lain: Satu, biro jodoh online secara umum hanya menyediakan kemudahan dalam mencari pasangan bagi kamu perempuan dan laki-laki secara online dan mengisi beberapa formulir data pribadi seperti foto, 
pekerjaan, usia dan lainnya. Hal ini bisa menjadi rujukan bagi perempuan atau lak-laki dalam menentukan pilihan pasangannya. Namun berbeda dengan rumah ta'aruf yang menyediakan kajian terkait konsep pernikahan yang baik dan bahagia serta langgeng sesuai ajaran agama. Serta pertemuan ditentukan misalnya sebanyak 16 kali atau minimal 8 kali pertemuan. (Rusdi, 2019: 41-42)

Dua, biro jodoh online biasanya menggunakan sosial media dalam berkenalan dengan lawan jenis dan meminta untuk dicarikan pasangan yang sekira cocok untuk menjalin hubungan, seperti diperkenalkan dan nantinya mereka membuat janji untuk bertemu langsung maupun menggunakan percakapan di smartphone. Sedangkan dalam rumah ta'aruf berbanding terbalik dengan hal tersebut, maksudnya pihak perempuan dan laki-laki yag sudah diperkenalkan tidak dibolehkan bertemu atau menjalin hungan tanpa didamping orang lain.

Tiga, dalam biro jodoh online pihak pengelola biro tidak melakukan pendampingan terhadap kedua belah pihak sampai menikah, pengelola biro memberikan kemudahan dalam mencari informasi dan pasangan yang dinilai cocok oleh pengguna. Hal tersebut bertolak belakang dengan proses rumah ta'aruf, pihak perempuan dan laki-laki yang memiliki kecocokan dikeduanya akan meminta untuk berta'aruf kemudian lembaga akan menyediakan proses lamaran hingga menikah.

Empat, pda umumnya biro jodoh onlinememakai sosial media untuk memperlihatkan identitas dan profil masaing-masing di situs mereka. Sedang- kan pada rumah ta'aruf, tidak memakai jejaring sosial dan media online lainnya untuk menginformasikan identitas dan profil para ta'aruf, termasuk proses perkenalan di antara mereka. Hal ini memiliki alasan bahwa menggunakan jejaring sosial kurang memberikan informasi atau diri pasangan yang valid. Hanya saja sosial media diaplikasikan untuk menyusun dan menetukan jadwal serta hal-hal yang berkaitan dengan kegiatan ta'aruf. (Rusdi, 2019: 43)

\section{DAMPAK POSITIF DAN NEGATIF PENGGUNAAN BIRO JODOH ONLINE}

Penggunaan aplikasi biro jodoh online tentu juga terdapat dampak positif maupun negatif, namun itu semua tergantung pada penggunanya. Dampak positif yang diberikan yaitu dimasa pandemic saat ini setiap orang dapat memanfaatkan media social dalam mencari dan berkenalan serta dapat memilih kriteria pasangan sesuai dengan yang kita inginkan. Pemakaian yang mudah,dapat menghemat waktu dan menjadi solusi bagi seseorang yang punya sifat tertutup. dampak negatif yang harus kita berhati-hati dalam menggunakan aplikasi biro jodoh onlineyaitu dapat menimbulkan persoalan mengenai akses data pribadi dan rentan terhadap cyber crime (kejahatan online). Arus perkembangan teknologi yang begitu cepat melahirkan situs terbaru berbentuk biro jodoh online, namun lebih terkesan ke arah media sosial dan tidak memerhatikan nilai-nilai Islam, seperti bebas melakukan chat 
dengan lawan jenis dan dapat dengan mudahnya bertukar informasi pribadi.

Aplikasi biro jodoh online memiliki kelebihan dan kekurangan pada pemakaiannya. Kelebihan dari aplikasi biro jodoh online yaitu, pemanfaatan media sosial dalam mencari pasangan tidak saja mempermudah proses perkenalan, tetapi juga berpotensi dalam banyaknya kriteria calon pasangan dan memperbesar peluang untuk mendapatkan calon pasangan yang paling sesuai dengan kriteria yang diinginkan. Namun demikian, kekurangan dari aplikasi biro jodoh online yaitu, sangat berpotensi dalam menimbulkan persoalan dalam kaitan dengan akses terhadap data pribadi dan rentan terhadap cyber crime (kejahatan online).

Upaya pencarian jodoh dalam kehidupan setiap orang adalah manusiawi, bahkan pada zaman dahulu, pencarian jodoh seringkali diatur dan adanya intervensi oleh orang tua atau kerabat dekatnya. Peran kerabat dalam menentukan jodoh dahulu sangat dominan, namun dengan terus berkembangnya ilmu pengetahuan dan teknologi digital peran seperti itu mulai menyusut dan digantikan oleh peran individu masingmasing dalam menentukan dan memilih jodohnya. (Meilani, 2014: 82) Berikut ini beberapa alasan dari masyarakat yang memilih mencari pasangan melalui biro jodoh online antara lain:

a. Kemudahan mengakses aplikasi

Kemudahan mengakses aplikasi biro jodoh atau media sosial lainnya menjadi tolak ukur masyarakat untuk mencari calon pasangan di dunia maya, dikarenakan hal tersebut tidak memakan banyak biaya dan waktu hanya sekedar untuk bertemu dengan calon pasangan, cukup melalui mobile phone masyarakat sudah bisa mengakses aplikasi tersebut. b. Efisiensi waktu

Biro jodoh online dan sosial media lainnya membantu untuk mengenal orang dari belahan kota manapun sehingga adanya peluang untuk memilih calon pasangan yang diinginkan bisa menjadi lebih luas hanya cukup berkomunikasi via mobile phone. Selain itu, tidak perlu menyediakan tempat, meluangkan waktu untuk bertemu orang baru dan berkencan. Karena melakukan pendekatan di dunia maya tidak banyak menyita banyak waktu.

c. Kurang percaya diri

Alasan lain seseorang memilih mencari jodoh lewat biro jodoh online dikarenakan kurang percaya diri untuk bertemu atau menemukan calon pasangannya di dunia nyata. Bagi beberapa orang melakukan pendekatan dengam cara bertemu di dunia nyata secara langsung adalah hal yang tidak mudah. Mereka menganggap melakukan pendekatan dan berkenalan di dunia maya lebih terasa gampang, sehingga dengan adanya biro jodoh online dan media sosial lainnya dinilai memudahkan dan membantu menjawab persoalan beberapa orang dalam mencari pasangan mereka.

d. Aktivitas/rutinitas yang padat

Bagi para pencari calon pasangan yang sibuk dengan mengurusi kegiatan/pekerjaan sehari-hari, banyak aktivitas sehingga membuat mereka mengesampingkan perihal asmara. Terlebih lagi tingkat kesibukan para masyarakat kota dalam menjalankan aktivitas kereja mereka setiap hari dan hubungan masyarakat yang cenderung individualis menyebabkan sering kali dikesampingkan demi karir. Maka alternatif dari permasalahan tersebut adalah dengan bersosialisasi di dunia 
maya seperti mengikuti biro jodoh online (onlinedating). Sebab, perputaran waktu yang sangat cepat membuat masyarakat sulit memenuhi kebutuhan hubungan asmara.

e. Nyaman

Nyaman memilih biro jodoh online sebagai tempat mencari calon pasangan dikarenakan semuanya telah diatur dan diurus oleh operator dari biro jodoh online yang dipilih tersebut dan si pengguna hanya menjalankan saja. Sebagian orang ada yang menganggap mencari pasangan dan pendekatan di dunia nyata itu susah, maka mereka mencari sesuatu yang nyaman dan lebih mudah tetapi tetap mendapatkan pasangan.

Mengikuti biro jodoh online sudah menjadi tren dikalangan masyarakat, terutama di Indonesia. Dengan berbagai alasan seperti segudang aktivitas di dunia kerja yang mengakibatkan banyak dari mereka mengabaikan perihal asmaranya. Rutinitas kerja yang padat yang membuat mereka sulit untuk bertemu dengan orang baru. Oleh karena itu, dengan adanya biro jodoh online seolah menjadi jawaban dan solusi yang tepat. Kehadiran onlinedating atau aplikasi biro jodoh di dunia maya (biro jodoh online) merupakan jawaban atas kebutuhan masyarakat dalam mencari pasangan. Dan kehadiran onlinedating atau aplikasi biro jodoh di dunia maya (biro jodoh online) merupakan jawaban atas kebutuhan masyarakat dalam mencari pasangan dan merubaha perilaku sosial masyarakat Indonesia dalam mencari jodoh membuat para kaum lajang tidak segan untuk mencari pasangan hidupnya di dunia maya.
Meskipun menggunakan biro jodoh online menjadi aplikasi yang memudahkan dalam pencarian pasangan, penggunaan biro jodoh online memiliki dampak negatif yaitu:

a. Rentan terhadap cyber crime

Cyber crime merupakan istilah untuk tindakan kejahatan dalam dunia sosial media dengan memanfaatkan kemajuan teknologi computer. Para pelaku menggunakannya sebagai alat sekaligus sasaran perbuatan mereka. Adapun beberapa contoh dari kejahatan dalam sosial media dalam pemalsuan cek, pornografi, penipuan identitas, membobol akun pribadi seseorang dan lain-lain.

b. Data palsu

Data yang diperoleh dalam menemukan identitas tidak valid atau tidak sesuai dengan yang asli, ada oknum-oknum yang memalsukan.

c. Rawan tindak pelecehan seksual

Sudah lazim mendengar banyak pengguna yang mengalami tindak pelecehan seksial yang diawali dengan perkenalan di jejaring sosial. Para korbannya kebanyakan masih labil dan masih awam dalam pemanfaatan jejaring sosial.

d. Pornografi

Penyalahgunaan sosial media juga bisa digunakan untuk hal-hal yang berbau sara atau pornografi. Tujuannya adalah untuk merusak pribadi seseorang yang merupakan pemilik privasi baik berupa gambar atau video namun disebarluaskan oleh penyalahgunaan sosial media. Ada juga yang melalui situs di sosial media, meskipun dengan bentuk yang sama seperti menyebarkan gambar dan 
video pornografi namun dengan tujuan menjual diri baik dari pelaku sendiri secara langsung atau tidak.

e. Menghabiskan banyak biaya pulsa atau kouta internet

Biaya untuk mengakases internet cukup mahal apalagi buat para pelajar/mahasiswa yang punya keuangan terbatas. Belum lagi kouta internet terbatas sehingga dibuthkan pemanfaatan yang lebih bijak dari penggunanya.

Berdasarkan dari dampak-dampak di atas, meskipun dampak baik dan buruknya media sosial itu tegantung pada tujuan dari penggguna itu sendiri. Namun apabila digunakan dengan cara tidak mentaati Undang-Undang ITE atau melanggar aturan dan nilai-nilai agama dan moralitas maka dapat memberikan dampak yang buruk bagi pengguna itu sendiri maupun pengguna sosial media lainnya. (Aljawiy, 2011: 6)

\section{KESIMPULAN}

Pengalihan konsep biro jodoh dari offline ke online bukanlah hal yang baru. Biro jodoh online adalah suatu layanan atau jasa yang disediakan khusus bagi masyarakat untuk mencari pasangan pada aplikasi online dating. Pada setiap aplikasi biro jodoh online memiliki metodenya masing-masing. Ada yang menggunakan metode konvensional dan adapula yang syari'ah sesuai ketentuan hukum dalam Islam. Aplikasi biro jodoh online pada zaman modern saat ini sangat dibutuhkan oleh masyarakat, terutama yang sulit dalam menemukan pasangan.

Manfaat dari adanya biro jodoh online adalah untuk mempermudah proses perkenalan yang disebabkan oleh tingginya mobilitas masyarakat perkotaan yang bekerja dari pagi hingga larut malam setiap harinya dan adanya rasa kurang percaya diri dari setiap pengguna, serta memperbesar peluang untuk mendapatkan calon pasangan yang paling sesuai dengan kriteria yang diinginkan melalui biro jodoh online.Manfaat lainnya yaitu kemudahan dalam mengakses aplikasi biro jodoh online tersebut.

Konsep aplikasi biro jodoh online diharapkan dapat digunakan dalam mencari pasangan yang cocok dan diinginkan sampai ke jenjang pernikahan. Disamping itu, yang harus diperhatikan bahwa aplikasi biro jodoh online juga dapat berpotensi menimbulkan persoalan dalam mengakses data pribadi dan rentan terhadap cyber crime.

\section{DAFTAPUSTAKA}

Al-Asqalani, I. H. (2000). Bulughul Maram. Pustaka Amani.

Aljawiy, A. Y. dan A. M. (2011). Jejaring Sosial dan Dampak bagi Penggunanya. Unipdu, 1-7.

Antar Venus dan Hikamul Had Ridwan. (2015). Eksplorasi Media Komunikasi Pencarian Jodoh Online: Studi Kasus Setipe.com. Analisis Politik Lampung, 7, 1-15.

Ash-Shobuni, M. A. (2008). Pernikahan Islami. Mumtaza.

Azzam, A. A. M. dan A. W. S. H. (2014). Fiqh Munakahat. Amzah.

Azzulfa, F. A. (2020). Biro Jodoh Online: Kebutuhan atau Tuntutan. Hukum Islam Nusantara, 3(1), 35-49.

Bungin, B. (2008). Sosiologi Komunikasi. Prenada Media Grup.

Hadikusuma, H. (1990). Hukum Perkawinan Indonesia. Mandar Maju.

Hakim, I. N. (2018). Pergeseran Budaya 
Siber \& Visual di Sektor Pariwisata Indonesia Respon Kementerian Pariwisata Menghadapi era Tourism 4.0 Melalui Peran Komunitas Milenial \& Pengembangan Destinasi Digital. Seminar Nasional Seni Dan Desain, 275.

Herdianti, A. H. (2018). Pencarian Jodoh Melalui Aplikasi Tinder Di Era Digital. S1 Sosiologi FISIP UNAIR, 3(1), 1-15.

Lestari, A. (2019). Ta'aruf Online dan Offline: Menjemput Jodoh Menuju Pernikahan. Emik Universitas Hasanuddin, 2(2), 1-21.

Meilani, N. L. (2014). Artikulasi Persepsi dan Preferensi Pemanfaatan Biro Jodoh Oleh Perempuan. Parellela, 1(1), 77-88.

Rasyid, S. (2010). Fiqh Islam. Sinar Baru Algesindo.

Rusdi. (2019). Kencan Islami: Studi Antusiasme Mahasiswa Mengikuti Kajian dan Praktik Ta'aruf di rumah Ta'aruf Majelis Calon Ayah Amanah Yogyakarta. Universitas islam Negeri Sunan Kalijaga.
Sita, A. P. (2013). Model Biro Jodoh Islami dalam Perkawinan (Studi Kasus Peran Lembaga Biro Jodoh Islami Etty Sunanti di Surabaya). Studi Hukum Islam, 2(2), 1-12.

Syarifuddin, A. (2003). Garis-garis Besar Figh. Kencana.

Tarigan, F. A. (2017). Sistem Biro Jodoh Online. Majalah Ilmiah INTI, 5(1), 20 24.

Tihami dan Sohari Sahrani. (2014). Fikih Munakahat: Kajian Nikah Lengkap. Rajawali Press.

Uwaidah, S. K. M. (1998). Fiqih Wanita Edisi Lengkap. Pustaka Al-Kautsar.

Waluyo, L. S. dan I. R. (2019). Pertukaran Sosial dalam Online Dating (Studi Pada Pengguna Tinder di Indonesia). Informatik, 15(1), 21-38.

We Are Social. (n.d.). https://m.detik.com.

Zed, M. (2008). Metode Penelitian Kepustakaan. Yayasan Obor Indonesia. 